\title{
Frequencies, sensitivity pattern and molecular characterization of bacterial isolates in blood in neonatal sepsis.
}

1. MBBS, M.Phil (Microbiology) Assistant Professor Pathology Sahara Medical College.

2. MBBS, M.Phil (Microbilogy) Demonstrator Pathology Sahara Medical College

3. M.Phil (Microbiology)

Assistant Professor Pathology Sahara Medical College.

Correspondence Address: Dr. Saeeda Nabat ul Hassan Department of Pathology Sahara Medical College Narowal. doctor.saeeda@gmail.com

Article received on: 05/08/2020

Accepted for publication: $28 / 12 / 2020$

\begin{abstract}
Saeeda Nabat ul Hassan', Ghulam Asghar Bhutta², Khushbu Farva ${ }^{3}$
ABSTRACT... Objective: To determine frequency, molecular characterization and sensitivity of bacterial isolates against commonly used antibiotics in neonatal sepsis. Study Design: Cross Sectional study. Setting: Department of Pathology Sahara Medical College Narowal. Period: October 2019 to March 2020. Material \& Methods: Neonates admitted in neonatal intensive care unit (NICU) of study institution having signs and symptoms of neonatal symptoms such as fever, irritability, seizures, anorexia and lethargy, were included in the study using consecutive sampling technique. Blood sample from all study patients taken and sent for culture to determine bacterial isolates and antibiotic sensitivity against commonly used antibiotics for neonatal sepsis. Bacterial isolates identification was done using standard bacteriological technique performed by modified Kirby \& Bauer disc diffuse method as per Clinical and Laboratory standards institute (CLSI) guidelines. Results: Total 200 cases were studied having neonatal sepsis and admitted in NICU including $58 \%$ female and $42 \%$ male children. Bacterial growth occurred in $10.5 \%$ samples and in $89.5 \%$ samples no bacterial growth seen. There were $1 \%$ samples with gram positive and $9.5 \%$ samples with gram negative bacterial isolates. Klebsiella was the commonest organism isolated in $38.1 \%$ cases out of total positive isolates. There were $72.5 \%$ neonates having age 1-14 days and 27.5\% neonates having age 15-28 days. Conclusion: Gram negative bacteria are common cause of neonatal sepsis, out of which Klebsiella is the commonest organism. Antimicrobial drug resistance in different infections is a serious emerging issue.
\end{abstract}

Key words: $\quad$ Antibiotic Resistance, Antibiotic Sensitivity, Gram Positive Bacteria, Gram Negative Bacteria, Neonatal Sepsis.

Article Citation: Nabat ul Hassan S, Bhutta GA, Farva K. Frequencies, sensitivity pattern and molecular characterization of bacterial isolates in blood in neonatal sepsis. Professional Med J 2021; 28(7):987-992. https://doi.org/10.29309/TPMJ/2021.28.07.5902

\section{INTRODUCTION}

Septicemia in first month of child is called neonatal sepsis. Sepsis is a systemic condition characterized by bacteremia causing dysfunction of body organs. It is a lethal condition which should be immediately treated by sensitive and effective antibiotics. ${ }^{1}$ Signs and symptoms of sepsis are fever, seizures, anorexia, lethargy, tachycardia, tachypnea etc. There are two types of neonatal sepsis first is early onset sepsis occurring from birth to $7^{\text {th }}$ day of age, late onset sepsis occurs from 7th till completion of first month of life. Incidence of neonatal sepsis is high in developing and underdeveloped countries and low incidence in developed countries. According to a report its incidence is $1-4 / 1000$ live births due to septic deliveries and good neonatal care. ${ }^{2}$ Mortality rate of neonates in Pakistan is $49 / 1000$ live births. ${ }^{1,3}$ According to a study in neonatal sepsis gram positive bacteria are commonly found. In developing countries 1.6 million neonatal deaths occur each year due to neonatal sepsis. ${ }^{2}$ Out of total neonatal deaths worldwide $7 \%$ occur in Pakistan and its main cause is neonatal infection occurring in $33 \%$ neonates. $^{3}$ Sepsis is very common in underweight children. In Pakistan $25 \%$ of cases with neonatal sepsis have either low weight or very low weight. ${ }^{4}$ Early use of suitable empirical antibiotic regimen in neonatal sepsis reduces drug resistance and morbidity and mortality as well. A study conducted in Australia concluded gram positive bacteria as most common cause of neonatal sepsis and among them staphylococcus 
were most common microbe. ${ }^{5} \mathrm{~A}$ similar study conducted in India reported Klebsiella and E-coli as the commonest organisms in neonatal sepsis. Antibiotic susceptibility changes in developed and developing countries. ${ }^{6}$

Neonatal sepsis is a common cause of death in preterm neonates admitted in ICU. In 2010 7.6 million neonates died worldwide due to infections and neonatal sepsis. ${ }^{7}$ In 1990 death rate of neonates was $37 \%$ out of total deaths in children under five years of age, which increased to $44 \%$ in $2013 .{ }^{8,10}$ In developed countries despite much developed healthcare services, four out of ten neonates die due to sepsis or suffer from permanent disability. ${ }^{8}$ In USA $36 \%$ of neonates born before 28 weeks of gestation suffer from one episode of infection at least during their birth hospitalization with $50 \%$ mortality rate. Compared to term babies, in preterm babies, sepsis is 1000 times more common. ${ }^{9}$ According to a report published in 2016, mortality rate of under 5 years was 64.6 per 1000 live births in poorest households, and 31.3 per 1000 live births in richest households and those having in between socioeconomic status were having mortality rate between 64.6-31.3/1000 live births. Before prescribing antibiotic therapy it is very important to have knowledge of most common bacteria causing neonatal sepsis so that we may give proper treatment. There is very little data available from our country regarding common bacteria causing neonatal sepsis and most effective antibiotics against them, so this study was conducted so that we may treat children properly having neonatal sepsis and we may reduce mortality and morbidity rate as well.

\section{MATERIAL \& METHODS}

This is a cross sectional study conducted in department of pathology Sahara Medical College Narowal. Study was started in October 2019 and completed after six months in March 2020. Inclusion and exclusion criteria were applied for selection of cases for study. Neonates admitted in neonatal intensive care unit (NICU) of study institution with age of 1-28 days having signs and symptoms of neonatal symptoms such as fever, irritability, seizures, anorexia and lethargy, were included in the study using consecutive sampling technique. Neonates having congenital anomalies of heart, gastrointestinal tract and kidneys etc were excluded from the study. Base line and specialized investigations done. Blood sample from all study patients taken and sent for culture to pathology laboratory of study institution, to determine bacterial isolates and antibiotic sensitivity against commonly used antibiotics for neonatal sepsis. Bacterial isolates identification was done using standard bacteriological technique performed by modified Kirby \& Bauer disc diffuse method as per Clinical and Laboratory standards institute (CLSI) guidelines. P-value < 0.05 was considered significant. Sample size was calculated using WHO sample size calculator with confidence level was 95\% and margin of error was $5 \%$, population anticipated proportion taken $8 \%$ and absolute precision was $4 \%$. Sampling was done by non-probability consecutive sampling technique. Data calculated was documented on a performa and data analysis done on SPSS software. Percentage, frequency, means and standard deviation determined. Chi square test was applied on data. Consent was taken from all the patients for including their data into the study. Ethical approval was also taken from the institutional ethical review committee.

\section{RESULTS}

Total 200 cases were studied having neonatal sepsis and admitted in NICU including 116(58\%) female and 42(42\%) male children. Bacterial growth occurred in $21(10.5 \%)$ samples and in $79(89.5 \%)$ samples no bacterial growth seen. There were $2(1 \%)$ samples with gram positive (enterococcus) and 19(9.5\%) samples with gram negative bacterial isolates. Gram negative bacteria included Acinetobacter in 3(1.5\%) samples, E.coli in $4(2 \%)$ and Pseudomonas in $4(2 \%)$ samples. Klebsiella was the commonest organism isolated in $38.1 \%$ cases out of total gram-negative isolates. There were $72.5 \%$ neonates having age 1-14 days and $27.5 \%$ neonates having age $15-28$ days.

25\% Klebsiella were sensitive to Meropenem and Tazobactum, 25\% Pseudomonas were sensitive to Amikacin and Ceftazidime, $50 \%$ were sensitive to Gentamycin and Meropenem and $100 \%$ were 
sensitive to Tazobactum. 50-100\% Enterococcus were sensitive to Ampicillin, Amikacin and Vancomycin. 33-66\% Acinetobacter were

\begin{tabular}{|c|c|c|c|c|c|c|c|}
\hline \multicolumn{2}{|c|}{ Micro-organism Isolated } & Age (1-14 days) & \multicolumn{2}{|c|}{ Age (15-28 days) } & \multicolumn{2}{|r|}{ Total } & P-Value \\
\hline \multicolumn{2}{|c|}{ E-coli (Negative) } & $3(14.3 \%)$ & \multicolumn{2}{|c|}{$1(4.8 \%)$} & \multicolumn{2}{|c|}{$4((19.1 \%)$} & \multirow{4}{*}{$<0.01$} \\
\hline \multicolumn{2}{|c|}{ Acinetobacter (Negative) } & $3(14.3 \%)$ & \multicolumn{2}{|l|}{0} & \multicolumn{2}{|c|}{$3(14.3 \%)$} & \\
\hline \multicolumn{2}{|c|}{ Klebsiella (Negative) } & $5(23.8 \%)$ & \multicolumn{2}{|l|}{$3(14.3)$} & \multicolumn{2}{|c|}{$8(38.1 \%)$} & \\
\hline \multicolumn{2}{|c|}{ Enterococcus (Positive) } & $1(4.8 \%)$ & \multicolumn{2}{|c|}{$1(4.8 \%)$} & \multicolumn{2}{|c|}{$2(9.5 \%)$} & \\
\hline $\begin{array}{c}\text { Bacterial } \\
\text { Sensitivity Pattern }\end{array}$ & $\begin{array}{c}\text { E.coli } \\
n=4\end{array}$ & $\begin{array}{l}\text { Acinetobacter } \\
\qquad n=3\end{array}$ & $\begin{array}{l}\text { Pseudomonas } \\
n=4\end{array}$ & & & $\begin{array}{l}\text { Enterococcus } \\
\qquad n=2\end{array}$ & P-Value \\
\hline Amikacin & $4(100 \%)$ & $1(33.3 \%)$ & $1(33.3 \%)$ & & & $1(50 \%)$ & \multirow{6}{*}{$<0.05$} \\
\hline Meropenem & $2(50 \%)$ & $2(66.6 \%)$ & $4(100 \%)$ & & & $1(50 \%)$ & \\
\hline Cloxacillin & $0(0 \%)$ & $0(0 \%)$ & $0(0 \%)$ & & & $0(0 \%)$ & \\
\hline Vancomycin & $0(0 \%)$ & $0(0 \%)$ & $0(0 \%)$ & & & $2(100 \%)$ & \\
\hline Tazobactum & $0(0 \%)$ & $0(0 \%)$ & $4(100 \%)$ & & & $0(0 \%)$ & \\
\hline Gentamycin & $3(75 \%)$ & $1(33.3 \%)$ & $2(50 \%)$ & & & $0(0 \%)$ & \\
\hline
\end{tabular}

Table-II. Sensitivity of bacterial isolates against commonly used antibiotics for neonatal sepsis.

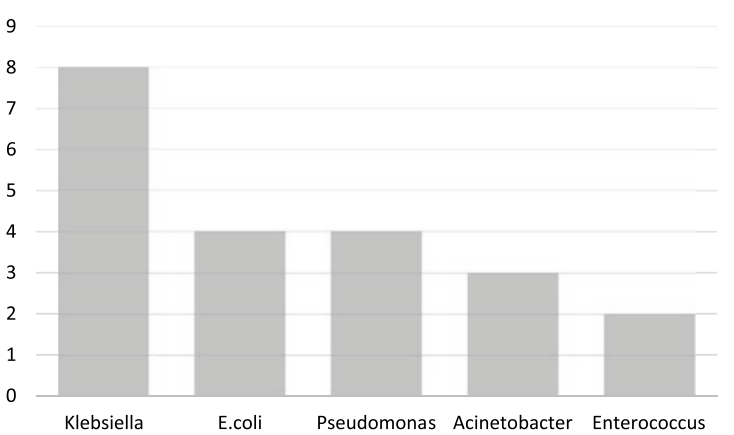

Figure-1. Frequency of various microbes isolated in blood. $(n=21)$

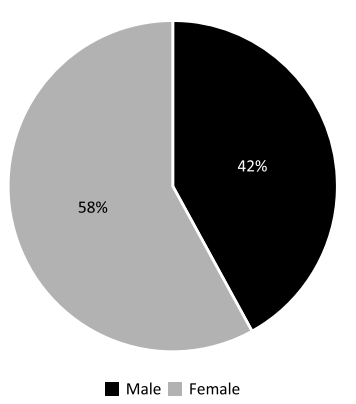

Figure-3. Sex distribution of neonates in study group $(n=200)$. sensitive to Ceftazidime and Meropenem. It was seen that Amikacin was effective against all these bacteria.

$$
(n=21) \text {. }
$$


of developing antibiotic resistance and failure of treatment. So diagnosis should be clinical and immediately empirical antibiotic therapy should be given in neonatal sepsis. ${ }^{12}$ Gold standard investigation for diagnosing neonatal sepsis is blood culture examination. ${ }^{13}$ In a study done in Ethiopia by Moges et al $46.6 \%$ cases shows bacterial growth in blood samples suspected for neonatal sepsis. Most commonly gram-positive bacteria were found in $67.5 \%$ cases including staphylococcus in $40.8 \%$ cases and Klebsiella found in $15.8 \%$ cases. In their study $70 \%$ isolates were multidrug resistant. ${ }^{14}$

In our study most commonly gram negative bacteria were isolated from blood samples in $90.5 \%$ cases and gram negative bacteria were isolated in $9.5 \%$ samples out of total isolates showing bacterial growth. This difference may be due to geographical factor. In our study most common isolated organism was Klebsiella found in $38.1 \%$ of samples showing bacterial growth. A similar study conducted in Nigeria reported predominant gram-positive organisms in 59\% and gram-negative in $41 \%$ cases of neonatal sepsis. In their study staphylococcus was most common and Klebsiella was second most common organism. ${ }^{15}$ Similar study has been conducted in Islamabad, in which $8 \%$ samples showed bacterial growth and $92 \%$ samples did not show any growth. They concluded gramnegative bacteria as predominant organisms found in $92.3 \%$ samples and gram positive in $7.7 \%$ samples. Out of total 13 positive isolates, most common isolated organism in their study was Klebsiella found in $38.5 \%$ samples followed by pseudomonas found in $23.1 \%$ samples, E.coli and acinetobacter in $15.4 \%$ and enterococcus isolated in $7.7 \%$ isolates. ${ }^{16}$ These results are similar to our study where gram negative organisms were predominant including Klebsiella as most common isolated organism. Other organisms in our study were E.coli found in $19.1 \%$, Pseudomonas in 19.1\%, Acinetobacter in 14.3\% and enterococcus isolated in $9.5 \%$ samples out of total 21 positive isolates.

In their study $20 \%$ Klebsiella were sensitive to Meropenem and Tazobactum, $50-100 \%$
E.coli were sensitive to Ampicillin, Amikacin, Gentamycin and Meropenem. 50\% Acinetobacter were sensitive to Amikacin, Gentamycin and Meropenem. ${ }^{16,17}$ These results are comparable to our study in which $25 \%$ Klebsiella were sensitive to Meropenem and Tazobactum, 25\% Pseudomonas were sensitive to Amikacin and Ceftazidime, 50\% were sensitive to Gentamycin and Meropenem and $100 \%$ were sensitive to Tazobactum. 50$100 \%$ Enterococcus were sensitive to Ampicillin, Amikacin and Vancomycin. 33-66\% Acinetobacter were sensitive to Ceftazidime and Meropenem. It was seen that Amikacin was effective against all these bacteria. Abdul Rehsamn et al reported coagulase negative Staph. Aureus most common isolating organism in $58.5 \%$ cases, followed by Coagulase positive Staph. Aureus in 16.6\% and E.coli in $7.6 \%$ cases. $^{18}$ In their study E.coli was common among Gram-negative organisms, but in our study it was second common organism after Klebsiella. In another study done by Shane et al, Klebsiella was isolated in $42 \%$ bacterial cultures followed by coagulase negative staph. aureus isolated in $19 \%$ cultures. ${ }^{19}$ A study done in Nigeria by Moges et al found predominance of gram-positive bacteria staphylococcus aureus in $59 \%$ specimens as compared to $11 \%$ cultures having Klebsiella P. (Gram-negative). ${ }^{23}$ A study done in Northwest Ethiopia reported Klebsiella the most common Gram negative organism found in $15.8 \%$ cultures. These results are similar to our findings. ${ }^{20}$ Selium et al and other authors also found increasing resistance among gram negative bacteria, as reported $96.9 \%$ resistance reported against ampicillin, 90.6\% resistance against amoxicillin-clavulanic acid and $84.4 \%$ resistance against cefotaxime and ceftazidime. ${ }^{21,22}$ New developments are being done to reduce prevalence of neonatal sepsis such as sepsis prediction scores to diagnose it without culture examination, proper antimicrobial use and introducing preventive measures like maternal vaccines etc. ${ }^{23}$

\section{CONCLUSION}

Gram-negative bacteria are common cause of neonatal sepsis and use of proper antibiotics according to sensitivity pattern can reduce morbidity, mortality and resistance against 
unnecessary use of antibiotics, so multidrug resistance in bacteria can be avoided. Antibiotic resistance is a main cause of treatment failure in neonatal sepsis, so isolation of bacteria from blood culture and starting antibiotic treatment according to sensitivity pattern can effectively treat the disease.

Copyright@ 28 Dec, 2020.

\section{REFERENCES}

1. MojtahediSY, Izadi A, Seirafi G, Khedmat L, Tavakolizadeh R. Risk factors associated with neonatal jaundice: A cross-sectional study from Iran. Open access Macedonian journal of medical sciences. 2018 Aug 20; 6(8):1387.

2. Molyneux EM, Dube Q, Banda F, Chiume M, Singini I, Mallewa $M$ et al. The treatment of possible severe infection in infants: an open randomized safety trial of parenteral benzylpenicillin and gentamicin versus ceftriaxone in infants $<60$ days of age in Malawi. The Pediatric infectious disease journal. 2017 Dec; 36(12):e328.

3. Haq I, Mustaan S, Ahmad A, Khan S, Said Z, Hussain S. Frequency of various bacteria and their antibiotics sensitivity in neonatal sepsis at tertiary care hospital. Journal of Saidu Medical College. 2019 Jun 12;9(1):7175.

4. Asghar S, Khan JA, Mahmood MS, Arshad MI, Dowling $D$, Schierholz E. A cross-sectional study of group B streptococcus-associated sepsis, coinfections, and antibiotic susceptibility profile in neonates in Pakistan. Advances in Neonatal Care. 2020 Aug 1; 20(4):E59-69.

5. Coetzee M, Mbowane NT, de Witt TW. Neonatal sepsis: Highlighting the principles of diagnosis and management. South African Journal of Child Health. 2017; $11(2): 99-103$.

6. Lebea MM, Davies V. Evaluation of culture-proven neonatal sepsis at a tertiary care hospital in Johannesburg, South Africa. South African Journal of Child Health. 2017; 11(4):170-3.

7. Liu L, Oza S, Hogan D, Chu Y, Perin J, Zhu J et al. Global, regional, and national causes of under-5 mortality in 2000-15: an updated systematic analysis with implications for the Sustainable Development Goals. The Lancet. 2016 Dec 17; 388(10063):3027-35.

8. Schüller SS, Kramer BW, Villamor E, Spittler A, Berger $A$, Levy $O$. Immunomodulation to prevent or treat neonatal sepsis: Past, present, and future. Frontiers in pediatrics. $2018 \mathrm{Jul} 19 ; 6: 199$.
9. Blencowe $\mathrm{H}$, Krasevec J, de Onis M, Black RE, An X, Stevens GA et al. National, regional, and worldwide estimates of low birthweight in 2015, with trends from 2000: A systematic analysis. The Lancet Global Health. 2019 Jul 1; 7(7):e849-60.

10. Rohit A, Maiti B, Shenoy S, Karunasagar I. Polymerase chain reaction-restriction fragment length polymorphism (PCR-RFLP) for rapid diagnosis of neonatal sepsis. The Indian journal of medical research. 2016 Jan; 143(1):72.

11. Russell $A B$, Kumar R. Early onset neonatal sepsis: diagnostic dilemmas and practical management. Archives of Disease in Childhood-Fetal and Neonatal Edition. 2015 Jul 1; 100(4):F350-4.

12. Coggins SA, Weitkamp JH, Grunwald L, Stark AR, Reese J, Walsh W, et al. Heart rate characteristic index monitoring for bloodstream infection in an NICU: A 3-year experience. Archives of Disease in ChildhoodFetal and Neonatal Edition. 2016 Jul 1; 101(4):F329-32.

13. Wynn JL. Defining neonatal sepsis. Current opinion in pediatrics. $2016 \mathrm{Apr}$; 28(2):135.

14. Moges F, Eshetie S, Yeshitela B, Abate E. Bacterial etiologic agents causing neonatal sepsis and associated risk factors in Gondar, Northwest Ethiopia. BMC pediatrics. 2017 Dec 1; 17(1):137.

15. Medugu N, Iregbu KC. Trends in profiles of bacteria causing neonatal sepsis in Central Nigeria hospital. African Journal of Clinical and Experimental Microbiology. 2017; 18(1):49-52.

16. Bashir Abbasi N, Jabeen N, Khatoon S. Neonatal sepsis; common bacterial isolates and their antimicrobial susceptibility patterns in neonatal intensive care unit, Islamabad. Professional Medical Journal. 2017 Oct 1; 24(10).

17. Abdulrahman Is, Saadi At. Bacterial isolates and their antimicrobial resistance patterns in neonatal sepsis recorded at Hevi Teaching Hospital in Duhok City/ Kurdistan Region of Iraq. Duhok Medical Journal. 2019; 13(2):84-95.

18. Mohsen L, Ramy N, Saied D, Akmal D, Salama N, Haleim MM, et al. Emerging antimicrobial resistance in early and late-onset neonatal sepsis. Antimicrobial Resistance \& Infection Control. 2017 Dec 1; 6(1):63.

19. Shane AL, Sánchez PJ, Stoll BJ. Neonatal sepsis. The lancet. 2017 Oct 14; 390(10104):1770-80.

20. Moges F, Eshetie S, Yeshitela B, Abate E. Bacterial etiologic agents causing neonatal sepsis and associated risk factors in Gondar, Northwest Ethiopia. BMC pediatrics. 2017 Dec 1; 17(1):137. 
21. Seliem WA, Sultan AM. Etiology of early onset neonatal sepsis in neonatal intensive care unit-Mansoura, Egypt. Journal of neonatal-perinatal medicine. 2018 Jan 1; 11(3):323-30.

22. Hammoud MS, Al-Taiar A, Al-Abdi SY, Bozaid H, Khan $A$, AlMuhairi LM, $R$ et al. Late-onset neonatal sepsis in Arab states in the Gulf region: Two-year prospective study. International Journal of Infectious Diseases. 2017 Feb 1; 55:125-30.
23. Medugu N, Iregbu KC. Trends in profiles of bacteria causing neonatal sepsis in Central Nigeria hospital. African Journal of Clinical and Experimental Microbiology. 2017; 18(1):49-52.

24. Chao F, You D, Pedersen J, Hug L, Alkema L. National and regional under-5 mortality rate by economic status for low-income and middle-income countries: a systematic assessment. The Lancet Global Health. 2018 May 1; 6(5):e535-47.

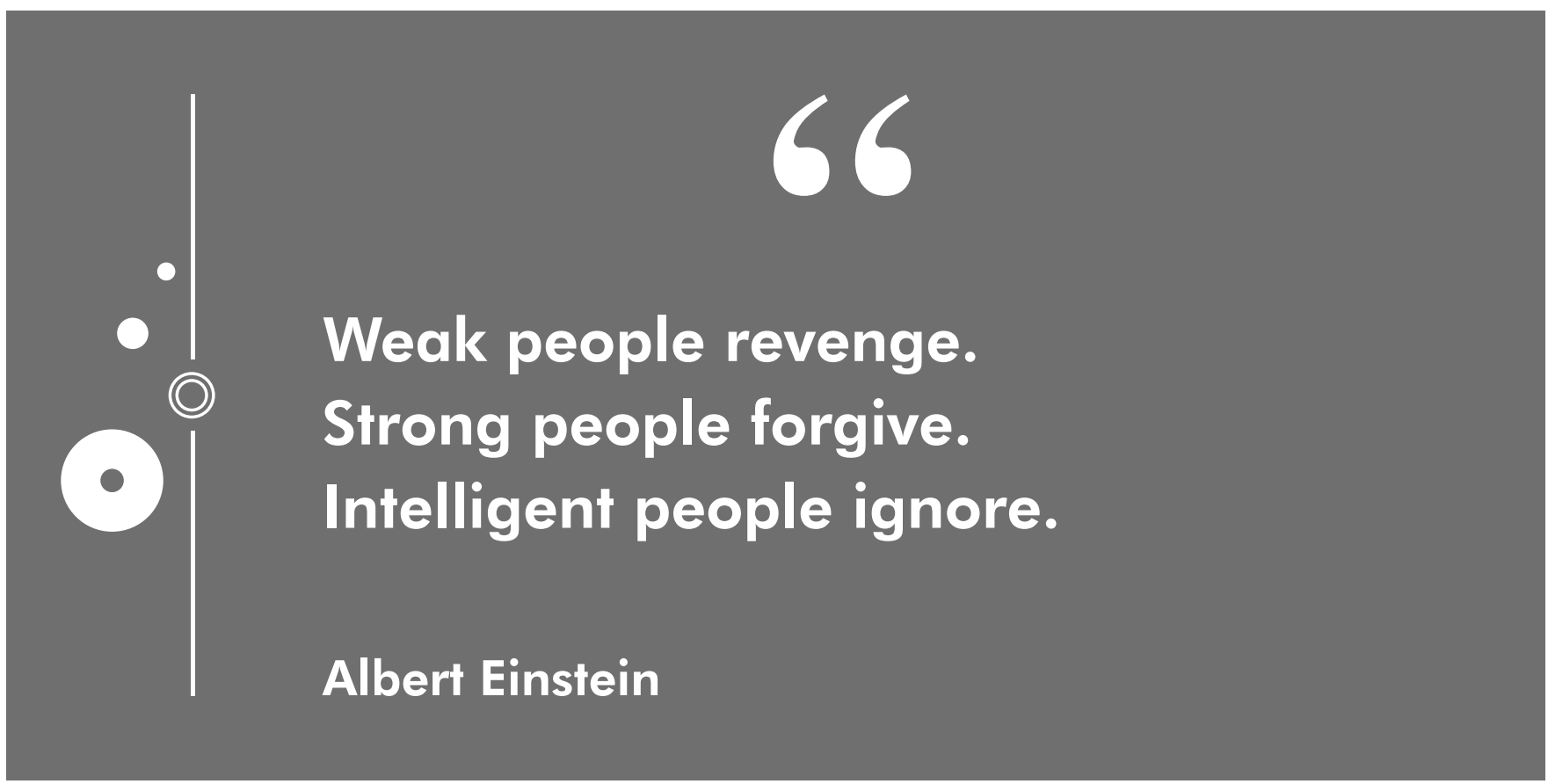

\begin{tabular}{|c|c|c|c|}
\hline \multicolumn{3}{|c|}{ AUTHORSHIP AND CONTRIBUTION DECLARATION } \\
\hline Sr. \# & Author(s) Full Name & Contribution to the paper & Author(s) Signature \\
\hline 1 & Saeeda Nabat ul Hassan & $\begin{array}{l}\text { Data analysis, Data collection, } \\
\text { Found additional literature for } \\
\text { information, Data composing. } \\
\text { Topic selection and data collection, } \\
\text { Abstract and recording. } \\
\text { Data collection, Found additional } \\
\text { sources of information. }\end{array}$ \\
\hline 2 & Ghulam Asghar Bhutta & Khushbu Farva & \\
\hline 3
\end{tabular}

